\title{
Relationship between Trees and Shrubs Biodiversity with Some Soil Physical Properties in Hyrcanian Forests (North of Iran)
}

\author{
Vahab Sohrabi (Corresponding author) \\ M.Sc. student Dept. of Forestry \\ Gorgan University of Agriculture Sciences and Natural Resources, Iran \\ Tel: 91-1857-2554...E-mail: sohrabivahab@yahoo.com \\ Hashem Habashi \\ Assistant Prof. Dept. of Forestry \\ Gorgan University of Agricultural and Natural Resources, Iran \\ E-mail: habashi@gau.ac.ir
}

Received: February 28, 2011 Accepted: July 27, 2011 doi:10.5539/ijb.v3n4p22

\begin{abstract}
In order to evaluation relationship between trees and shrubs biodiversity with some soil physical properties in hyrcanian forests, in range of 850-950 altitude from the sea level in 6 sites (in each site 30 plots) with least interfering of human in north aspect and with equal distance from each other were located. In this $20 * 50$ meter frame, the characteristic of trees and shrubs species (Species name \& diameter) recorded. The heterogeneity indices of simpson, shannon-wiener, simpson's reciprocal, and number of equally common used for the quantitative data. In each plot, four soil samples $(500 \mathrm{~g})$ taken in the depth ranges of $10-20-\mathrm{cm}$. After mixing its, one sample $(200 \mathrm{~g})$ was selected for laboratory. Physical properties of used in research are soil texture (percent of sand, silt, and clay), percent of soil saturation and bulk density. Results showed sand percent have positive correlation in all sites except Carpineo-Paroteum type. In addition, results showed clay percent has negative correlation in all sites. Thus, according to special site condition in forest types, appropriate technique should be base on knowledge of qualitative and quantitative condition of communities.
\end{abstract}

Keywords: Soil physical properties, Biodiversity indices, Oak, Beech

\section{Introduction}

Hyrcanian forests in Iran that mainly located in the north slopes of alborz mountain range are of the great important according to its unique characteristics such as extreme biodiversity (fauna and flora). The presence of valuable species like beech, oak, maple, hornbeam ... Increased the importance of these forests (Delghan Abazary \& Saqeb Talebi, 2007). For suitable maintaining, managing and harvesting of these forests, a comprehensive and scientific knowledge required and it is necessary for achievement of suatainable development and protection of natural ecosystems and their biodiversity to study the environmental factors and their effects in trees and shrubs biodiversity. Aware of the plant condition and soil characteristics of ecosystem is helpful in estimation of dynamic procedure of that ecosystem because these cases are the base of an ecosystem and have reciprocal effects (Mataji et al, 2010). The notable point is that distribution of plant communities on the earth is not accidentally, because each community includes a collection of plant species with similar ecological need and according to complex environmental condition, it selects the special area for itself (Mataji \& Saqeb Talebi, 2008). One of the important factors that have effect on the diversity and trees growth is the edaphic elements of each region (Mahmudi et al, 2003). Forest soils are the initial source of necessary food component for plant such as action of exchanging play and useless food component (Tesu et al, 2004 \& Johnson et al, 2000). The researchers' studies show that soil physical properties over the chemical properties of soil are more effective factor in the expansion and diversity of forest communities (Enright,2005, Mirzaie et al, 2009, Mataji et al,2009, Asadi, 2009). These soil properties have great role in plant growth by supplying of food and water, ventilation and easy permeability. Mirzaie et al (2009) compared biodiversity reaction of wood and grass species to the physiochemical and physiographical factors of Zagros forests. The results showed that in north slopes the 
diversity and richness of woody species with altitude from sea level and stone cover have positive correlation and have negative correlation with clay and sand, in the south slopes have negative correlation with clay and sand and have positive correlation with silt and stone cover percent. Moreover, the other important result is the appropriate response of woody species to the physical factors than chemical factors. Also mataji et al (2008) studied the plant and its relation with soil physical and chemical condition in Kheirud Kenar forests. The result showed that in studied plant communities, soil physic have more effective role.

\section{Material and method}

\subsection{The regions of study}

To investigation this study, 6 sites (beech stand of gorgan, carpino-parroteum of aliabad, carpinus betulus stand of azadshahr, carpino-quercetum of takht, oak stand of farsian and oak stand of loveh) in golestan province (north of Iran) are selected.

2.1.1 The Gorgan research and academic Shast Kalateh forest is located in the northern slope of alborz mountain range and this mountain range is stretched to the south of caspian sea from east and west. This forest is located latitude 36 degree and 47 minutes to 36 degree and 45 minutes to north and in longitude of 51 degree and 20 minutes to 54 degree and 21 minutes in east. Its expanse is 3116 hectares. Its annual rainfall measure is 649 millimeters.

2.1.2 The tavir forestry plane is expanded from 4 kilometer is south of fazel abad toward in vertical at distance with nodeh malek crossroads to fazel abad. (This series of forests placed between the longitude of 54-45-12 to 54-40-9 and latitude of 26-5-20 to 36-47-29). The annual rainfall measure is 474 millimeter.

2.1.3 Kohmian forestry plan is located in 98 watershed domain which is limited in north is village of kohmian, fazel abad, khanduz sadat and marzbone, in south and west to naeme's forestry plan and in east to vatan forestry plan. Its east longitude is 55-14-49 to 55-10-30 and its north width is 37-65-15 to 37-00-00 degrees.

2.1.4 The first series of the Takht forestry plan is located in the northeast of 91-watershade domain. The takht series of forests are limited from north to minudasht city, from south to yale sorkh, from east to rhg cheshmeh series and from west to narmehab river and the azadshahr forestry is located. The region has north altitude of 37-07 to 37-13-30 and east longitude 55-27-20 to 55-22-35. The rainfall measurement series has $475 \mathrm{~mm}$ that parcel of 106 with expanse of 76/5 hectares with 900 height of sea level by north aspect is choose.

2.1.5 Sijan kiaram forestry plan expanded in 900-1800 height of sea level which in south east of galikesh city in 93 water shade territory and galikesh forestry territory from the nature resource administration of gorgan and gonbad. The rainfall measurement is these regions are $65 \mathrm{~mm}$, which is variable between 486 to $856 \mathrm{~mm}$.

2.1.6 The third series of loveh (Cheshmeh-shapour) forestry plan is located in the east part of alborz mountain range in golestan province and with part of 94-watershade galikesh. It has longitude of 55-41-00 to 55-46-00 and latitude of 37-19-00 to 37-20-00. Its four boundaries are limited from north to terjali villages' lands, from south to the first series of loveh, from east to protected forests of national park of golestan and from west to mohammad ali valley and the fourth series forests.

\subsection{Research method}

This research is base on sampling by systematic random system and the center of plots in forest is determined. To study and investigation, the number of modified whittaker plots in range of 850-950 altitude from the sea level in 6 site (in each site 30 plots) with least interfering of human in north aspect and with equal distance from each other were located (Figure 1). In this $2 \times 50$ meter frame, the characteristic of trees and shrubs species (Species name \& diameter) recorded. The heterogeneity indices of simpson, shannon-wiener, simpson's reciprocal, and number of equally common used for the quantitative data. In each plot, four soil samples $(500 \mathrm{~g})$ taken in the depth ranges of 10-20- cm. After mixing its, one sample $(200 \mathrm{~g})$ was selected for laboratory. Totally, 180-soil samples obtained. The soil samples air-dried and passed through a 2- $\mathrm{mm}$ mesh sieve for later analysis. Physical properties of used in research are soil texture (percent of sand, silt, and clay), percent of soil saturation, porosity, and bulk density. Soil texture determined by hydrometer (de Castilho et al, 2006) and bulk density determined by clod method. For determine linear correlation between biodiversity indices and soil physical properties used of pearson coefficient.

\subsection{Diversity indices}

\subsubsection{Simpson's index}


The first non-parametric measure of diversity was proposed by Simpson (1949). Simpson suggested that diversity was inversely related to the probability that two individuals picked at random belong to the same species. For an infinite population this is given by:

$$
\begin{aligned}
& D=\text { Simpson's index } \\
& p_{i}=\text { Proportion of species } i \text { in the community }
\end{aligned}
$$

where:

$$
D=\sum p_{i}^{2}
$$

To convert this probability to a measure of diversity, most workers have suggested using the complement of Simpson's original measure:

$$
1-D=1-\sum\left(p_{i}\right)^{2}
$$

Thus:

$$
\begin{aligned}
& \text { Simpson's index of diversity }=\left\{\begin{array}{l}
\text { Probability of picking two } \\
\text { organisms at random that } \\
\text { are different species }
\end{array}\right\} \\
&=1-\left\{\begin{array}{l}
\text { Probability of picking two } \\
\text { organisms that are the } \\
\text { same species }
\end{array}\right\}
\end{aligned}
$$

Where

$$
\begin{aligned}
(1-D) & =\text { Simpson's index of diversity } \\
p_{i} & =\text { Proportion of individuals of species } i \text { in the community }
\end{aligned}
$$

2.3.2 Reciprocal of Simpson index

Williams (1964) and MacArthur (1972) used the reciprocal of Simpson's original formulation:

$$
\frac{1}{D}=\frac{1}{\sum p_{i}^{2}}
$$

where:

$$
\begin{aligned}
& 1 / D=\text { Simpson's reciprocal index }\left(=\text { Hill's } N_{2}\right) \\
& p_{i}=\text { Proportion of species } i \text { in the community }
\end{aligned}
$$

Hill (1973) called this reciprocal $N 2$.

\subsubsection{Shannon-wiener index}

The most popular measures of species diversity are based on information theory. This indeed assumes that individuals are randomly sample from an independently large population. This uncertainty can be measured by the Shannon-Wiener function:

$$
H^{\prime}=\sum_{i=1}^{s}\left(p_{i}\right)\left(\log _{2} p_{i}\right)
$$

where: 


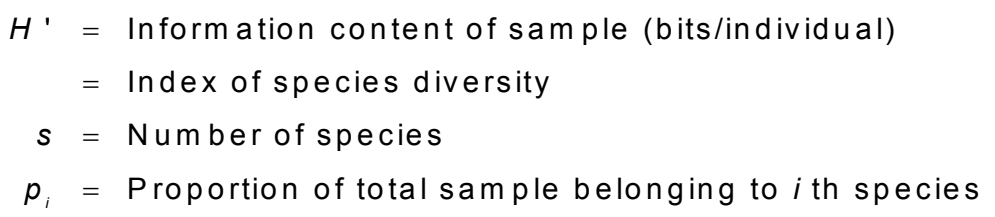

2.3.4 Number of equally common species index

The Shannon-Wiener index may be expressed in another form (MacArthur 1965) in units of numbers of species as:

$$
N_{1}=e^{H^{\prime}}
$$

where:

$$
\begin{aligned}
e & =2.71828 \text { (base of natural logs) } \\
H^{\prime}= & \text { Shannon-Wiener function (calculated with base } e \text { logs) } \\
N_{1}= & \text { Number of equally common species which would produce } \\
& \text { the same diversity as } H^{\prime}
\end{aligned}
$$

\section{Results}

Research results present in tables according to each site (1-6 tables).

In beech type, clay percent shows the most correlation and silt percent showed the least correlation with diversity indices. Sand percent, bulk density, soil saturation percent, and silt percent with diversity indices shows the positive correlation and clay percent shows the negative correlation with diversity indices (Table 1).

In Carpino-Paroteum type, silt percent shows the most correlation and the clay percent shows the least correlation with diversity indices. Silt percent, bulk density, soil saturation are represents positive correlation and clay percent, and sand percent shows negative correlation with diversity indices (Table2).

In Carpinus Betulus type, appearance bulk density display the most correlation and sand percent shows the least correlation with diversity indices. Apart from clay percent, other factors display positive correlation with diversity indices (Table3).

In Querco-Carpinetum type, sand percent represent the most correlation and soil saturation shows the least correlation with diversity indices. In this type sand percent and bulk density display positive correlation and clay percent, silt and soil saturation shows the negative correlation with diversity indices (Table 4).

In Farsian oak type, clay percent display the most correlation and silt percent demonstrate the least correlation with diversity indices. In this type sand and silt shows positive correlation and clay percent and soil, saturation demonstrates the negative correlation with diversity indices. Furthermore, appearance bulk density does not show special correlation with diversity standards (Table 5).

In Loveh oak type bulk, density display the most correlation and clay percent shows the least coefficient correlation with diversity indices. In this type sand percent, bulk density and soil saturation shows positive correlation and clay percent and silt display negative correlation with diversity standards (Table 6).

\section{Discussion}

Soil Physical and chemical factors and topography are the factors that effect on the presence and no presence of species (enright et al, 2005). Foresters usually identify the soil physical and chemical properties to estimates the sites capacity to maintain the production power of forests (Tesu et al, 2004). The research result display that physical properties are the most effective factor in growth, development and vegetation diversity (Mataji et al, 2010, Asadi 2010, Mirzaie et al, 2009, Enrihgt et al, 2005). As seen in the tables 1-6, sand shows positive correlation in all sites with biodiversity indices except Carpineo-Paroteum type. Clay shows negative correlation in all sites with biodiversity indices. According to the soil texture of under study sites that classified to the soils with small mid texture (Mahmudi et al, 2003) (Table7), it is natural that clay is negative factor and sand is positive in diversity, because clay restrict the permeability and sand increase the permeability. Therefore, by the increase of sand and decrease of clay, permeability increase and the plants can grow, develop, and finally enhance the diversity. Silt shows the positive correlation with diversity indices in all sites except Querco-Carpinetum and Loveh oak. In major soils fertility power or the ability of supplying necessary nutrition 
component in soil depends on silt particles. The useable moisture of soils that have large amount of silt is very high. This is due to the presence of desirable ratio of weather in this type of soils (Mahmoody et al, 2003). Therefore, it is suitable condition for increasing biodiversity. It is important to identify the soil texture and determine it for growth in species forest, because if nutrition in soil was enough but the roots could not grow and promote in soil though soil texture, the plant cannot utilize the necessary nutrition extremely.

On the other hand, soil texture with exist pore proper, can activate the soil microorganisms and provide required moisture for plant growth by good water supplying in soil (Habibi, 1984). Moreover, water nutrition in soil is more important than the mineral nutrition for some species like beech and oak and soil texture has significant role in the growth of this species (Mataji, 2009). Habibi (1974) point out that the best north beech forests of Iran is in the soil with clay loam, loam clay and light clay and in this soils the growth is very high. This results shows that water nutrition is very important in beech species. Soil stability against machines of logging and its tolerance depends on the texture and the amount of soil moisture (Mahmudi et al, 2003). The soils that have high amount of clay and organic matters, they have low tolerance in moist condition and can reduce and damage the diversity. So according to special site condition in forest types, appropriate technique should be base on Knowledge of qualitative and quantitative condition of communities and this case consider in forestry plans.

\section{Acknowledgements}

Hereby I give my gratitude to my parents that owed my life to them and also to my dear wife.

\section{References}

Asadi, H. (2009). Investigation of relationship hyrcanian buxus stands in khibus protected region by soil physicochemical factors. M.Sc thesis of Tarbiat Modarres University.

Decastilho, C. V., Magnusson, W. E., de Arau'jo, R. N. O., Luizão, R. C. C., Luizão, F. J., Lima, A. P., \& Higuchi, N. (2006). Variation in aboveground tree live biomass in a central amazonian forest: Effects of soil and topography. Forest ecology and management, 234: 85-96. http://dx.doi.org/10.1016/j.foreco.2006.06.024

Delfan Abazari, B \& Sagheb-Talebi, KH. (2007). Diameter and height increment process of oriental beech (Fagus orientalis) in natural Caspian forests; Kelardasht region. Iranian journal of forest and poplar research, 15(4).

Ejtehadi, H., Sepehry, A. \& Akkafi., H. R. (2009). Method of measuring biodiversity. Ferdoesi university of mashhad publication, No. 530.

Enright, N. J., B. P. Miller \& R. Akhtar. (2005). Desert vegetation and vegetation environment relationships in kirthar national park, Sindh,Pakistan. Journal of Arid Environments, 61: 397-418. http://dx.doi.org/10.1016/j.jaridenv.2004.09.009

Habibi, H. (1984). Investigation effect of soil texture on balance of beech growth in Iran. faculty of nature resource issue in tehran university, number 31: 60-69.

Johnson, C.E., Ruiz-Mendez, J. J \& Lawrence, G.B. (2000). Forest soil chemistry and terrain attributes in a catskill watershed. Soil Sci. Soc. Am. J. 64: 1804-1814. http://dx.doi.org/10.2136/sssaj2000.6451804x

Mahmudi, SH \& Hakimian,M. (2003). The basic of soil. Tehran university press, Tehran, Iran.

Mataji, A. \& Saqeb Talebi,KH. (2008). Investigation the process of diameter and height growth of beech in kelardasht virgin forests. Iranian journal of forest and poplar research. Vol. 15, No. 14: 320-328.

Mataji, A., Zahedi Amiri, Gh. \& Asri, Y. (2010). Vegetation analysis based on plant associations and soil properties in natural forests. Iranian journal of forest and poplar research. Vol. 17, No. 1.

Mirzaei, J., Akbarinia, M., Hosseini, S.M., Kohzadi, B. (2009). Biodiversity comparison of woody and ground vegetation species in relation to environmental factors in different aspects of zagros forest. Environmental science, Vol.5, No.3, spring.

Stohlgren, T. J., M. B. Falkner \& L. D. Schell. (1995). A modified-whittaker nested vegetation sampling method. Vegetation. 117(2): 113-121. http://dx.doi.org/10.1007/BF00045503

Tsui, ch. chen \& z. H, ch. (2004). Relationships between soil properties and slope positionin a lowland rain forest of southern taiwan.Geoderma. 123: 131-142. 
Table 1. Pearson correlation coefficient between soil physical properties and diversity indices in beech st

\begin{tabular}{lcccc}
\hline $\begin{array}{l}\text { soil physical } \\
\text { properties }\end{array}$ & $\begin{array}{c}\text { Number of equally } \\
\text { common species }\end{array}$ & Shannon-wiener & $\begin{array}{c}\text { Reciprocal of } \\
\text { Simpson }\end{array}$ & Simpson \\
\hline sand percent & $45 / 1^{*}$ & $44 / 8^{*}$ & $43 / 1 /^{*}$ & $46 / 3^{*}$ \\
$\begin{array}{l}\text { soil saturation } \\
\text { percent }\end{array}$ & $47 / 3^{*}$ & $41 / 5^{*}$ & $41 / 7^{*}$ & $40 / 8 / *$ \\
bulk density & $\mathbf{4 5 *}$ & $\mathbf{4 5 / \mathbf { 4 } ^ { * }}$ & $\mathbf{4 5} / *$ & $\mathbf{4 4 / \mathbf { 1 } ^ { * }}$ \\
clay percent & $-56 / 9^{* *}$ & $-61 / 7^{* *}$ & $-65 / 7^{* *}$ & $-50 / 3^{* *}$ \\
silt percent & $44 / 2^{*}$ & $-45 / 8^{*}$ & $46 / 3^{*}$ & $42 / 1^{*}$ \\
\hline
\end{tabular}

** Demonstrator significance in level $\mathrm{P}<0 / 01$

* Demonstrator significance in level $\mathrm{P}<0 / 05$

Table 2. Pearson correlation coefficient between soil physical properties and diversity indices in Carpino-Paroteum site

\begin{tabular}{lcccc}
\hline $\begin{array}{l}\text { soil physical } \\
\text { properties }\end{array}$ & $\begin{array}{c}\text { Number of equally } \\
\text { common species }\end{array}$ & Shannon-wiener & $\begin{array}{c}\text { Reciprocal of } \\
\text { Simpson }\end{array}$ & Simpson \\
\hline sand & $-* 52$ & $* *-54 / 3$ & $* *-54 / 9$ & $* *_{-} 58 / 5$ \\
clay & $*-42$ & $*-48 / 2$ & $*-41 / 2$ & $*-45 / 1$ \\
silt & $* * 63 / 4$ & $* * 65 / 4$ & $* * 56 / 6$ & $* 60 / 9$ \\
bulk density & $* 49 / 3$ & $* 47 / 6$ & $* * 50 / 3$ & $* 50 / 4$ \\
soil saturation & $* 41 / 4$ & $* 46 / 2$ & $46 / 3 *$ & $* 50 / 3$ \\
\hline
\end{tabular}

** Demonstrator significance in level $\mathrm{P}<0 / 01$

* Demonstrator significance in level $\mathrm{P}<0 / 05$

Table 3. Pearson correlation coefficient between soil physical properties and diversity indices in Carpinus Betulus site

\begin{tabular}{lcccc}
\hline $\begin{array}{l}\text { soil physical } \\
\text { properties }\end{array}$ & $\begin{array}{c}\text { Number of equally } \\
\text { common species }\end{array}$ & $\begin{array}{c}\text { Shannon-wien } \\
\text { er }\end{array}$ & $\begin{array}{c}\text { Reciprocal } \\
\text { of Simpson }\end{array}$ & Simpson \\
\hline sand & $* 41 / 4$ & $* 39 / 7$ & $* 44 / 2$ & $* 44 / 6$ \\
clay & $*-50 / 1$ & $* *-53 / 4$ & $*-45 / 1$ & $* *-51 / 3$ \\
silt & $* * 53 / 3$ & $* * 51 / 7$ & $* * 58 / 9$ & $* * 55 / 4$ \\
bulk density & $* * 58 / 6$ & $* * 60 / 3$ & $* * 57 / 6$ & $* * 58 / 4$ \\
soil saturation & $* * 50 / 9$ & $* * 53 / 4$ & $* * 54 / 8$ & $* * 55 / 7$ \\
\hline
\end{tabular}

** Demonstrator significance in level $\mathrm{P}<0 / 01$

* Demonstrator significance in level $\mathrm{P}<0 / 05$ 
Table 4. Pearson correlation coefficient between soil physical property and diversity indices in Querco-Carpinetum site

\begin{tabular}{lcccc}
\hline $\begin{array}{l}\text { soil physical } \\
\text { properties }\end{array}$ & $\begin{array}{c}\text { Number of equally } \\
\text { common species }\end{array}$ & Shannon-wiener & $\begin{array}{c}\text { Reciprocal } \\
\text { of Simpson }\end{array}$ & Simpson \\
\hline sand & $* * 59$ & $* 62 / 5$ & $* * 68 / 1$ & $* * 60 / 6$ \\
clay & $*-44 / 2$ & $* *-53 / 7$ & $* *_{-} 55 / 1$ & $* *_{-} 51 / 6$ \\
silt & $* *_{-} 56 / 9$ & $* *-52 / 8$ & $* *_{-} 60 / 4$ & $* *_{-} 71 / 5$ \\
bulk density & $* 46 / 1$ & $* 46 / 4$ & $* 45 / 9$ & $* 42$ \\
soil saturation & $*-40 / 7$ & $*_{-}-44 / 3$ & $*_{-} 42 / 7$ & $*_{-} 44 / 5$ \\
\hline
\end{tabular}

**Demonstrator significance in level $\mathrm{P}<0 / 01$

* Demonstrator significance in level $\mathrm{P}<0 / 05$

Table 5. Pearson correlation coefficient between soil physical properties and diversity indices in Farsian oak site

\begin{tabular}{ccccc}
\hline $\begin{array}{l}\text { soil physical } \\
\text { properties }\end{array}$ & $\begin{array}{c}\text { Number of equally } \\
\text { common species }\end{array}$ & Shannon-wiener & $\begin{array}{c}\text { Reciprocal of } \\
\text { Simpson }\end{array}$ & Simpson \\
\hline sand & $* * 54$ & $* * 54 / 8$ & $* 47$ & $* * 51 / 5$ \\
clay & $* *-54 / 5$ & $* *_{-} 60 / 6$ & $*-47 / 2$ & $* *-62 / 9$ \\
silt & $* 41 / 4$ & $* 47 / 1$ & $* 41$ & $* * 51 / 8$ \\
bulk density & $* *-54 / 4$ & $* *_{-} 57 / 5$ & $*-46 / 1$ & $* *-58 / 7$ \\
soil saturation & - & - & - & - \\
\hline
\end{tabular}

**Demonstrator significance in level $\mathrm{P}<0 / 01$

* Demonstrator significance in level $\mathrm{P}<0 / 05$

Table 6. Pearson correlation coefficient between soil physical properties and diversity indices in Loveh oak site

\begin{tabular}{ccccc}
\hline $\begin{array}{c}\text { soil physical } \\
\text { properties }\end{array}$ & $\begin{array}{c}\text { Number of equally } \\
\text { common species }\end{array}$ & Shannon-wiener & $\begin{array}{c}\text { Reciprocal of } \\
\text { Simpson }\end{array}$ & Simpson \\
\hline sand & $* * 59 / 7$ & $* * 56 / 3$ & $* * 66 / 6$ & $* * 59 / 5$ \\
clay & $*-42 / 3$ & $*-45 / 2$ & $*-40 / 1$ & $*-43 / 7$ \\
silt & $* *-51 / 8$ & $*-49 / 9$ & $* *-56 / 7$ & $* *-52 / 6$ \\
bulk density & $* * 64 / 1$ & $* * 64 / 2$ & $* * 58 / 9$ & $* * 60 / 3$ \\
soil saturation & $* * 57 / 4$ & $* * 56 / 5$ & $* * 52 / 2$ & $* 50 / 7$ \\
\hline
\end{tabular}

**Demonstrator significance in level $\mathrm{P}<0 / 01$

* Demonstrator significance in level $\mathrm{P}<0 / 05$

Table 7. Sites of research

\begin{tabular}{rrrr}
\hline site & soil texture & site & soil texture \\
\hline Beech & Clay-loam & Querco-carpinetum & Clay-loam \\
Carpino-paroteum & loam & Farsian oak & Sndy- Clay-loam \\
Carpinus betulus & loam & Loveh oak & Clay-loam \\
\hline
\end{tabular}




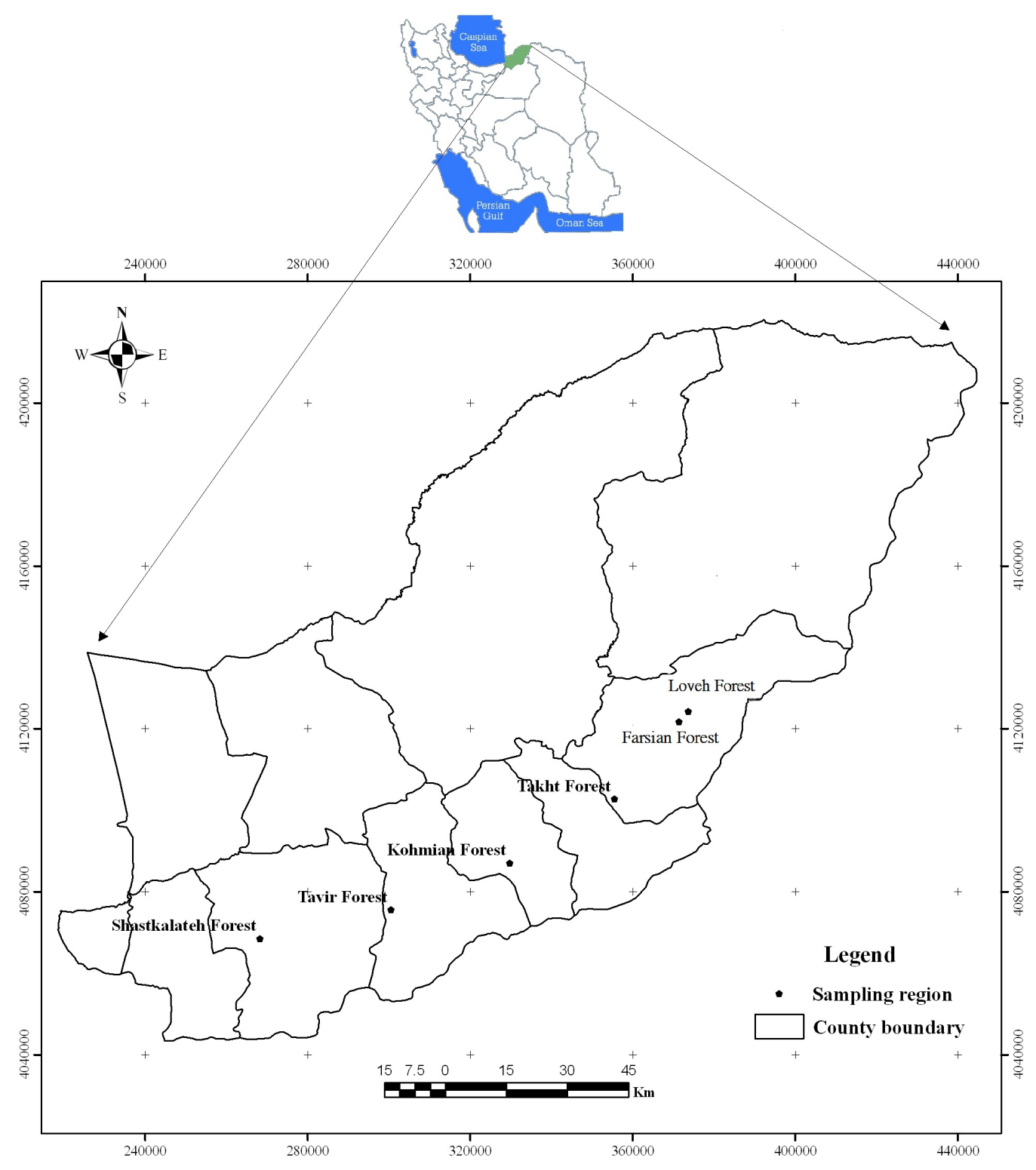

Figure 1. Map of the site study in golestan province, North of Iran 